\title{
Brazilian Protocol for Sexually Transmitted Infections, 2020: sexually transmitted enteric infections
}

\author{
Edilbert Pelegrini Nahn Junior ${ }^{[1]}$, Eduardo Campos de Oliveira ${ }^{[2]}$, Marcelo Joaquim Barbosa ${ }^{[3]}$, \\ Thereza Cristina de Souza Mareco ${ }^{[4]}$ and Helena Andrade Brígido ${ }^{[5]}$
}

[1]. Universidade Federal do Estado do Rio de Janeiro, Campus Macaé, RJ, Brasil

[2]. Secretaria Estadual de Saúde de Santa Catarina, Florianópolis, SC, Brasil

[3]. Secretaria de Saúde do Distrito Federal, Brasília, DF, Brasil

[4]. Ministério da Saúde, Brasília, DF, Brasil

[5]. Universidade Federal do Pará, Belém, PA, Brasil

\begin{abstract}
The sexually transmitted enteric infections topic is one of the chapters of the Clinical Protocol and Therapeutic Guidelines for Comprehensive Care for People with Sexually Transmitted Infections, published by the Brazilian Ministry of Health in 2020. The document was developed based on scientific evidence and validated in discussions with specialists. This article presents epidemiological and clinical aspects of these infections and guidance for service managers on their programmatic and operational management. The aim is to assist health professionals with screening, diagnosis, and treatment of people with sexually transmitted enteric infections and their sexual partners, in addition to supporting strategies for their surveillance, prevention, and control.
\end{abstract}

Keywords: Sexually transmitted diseases. Diarrhea. Sexual behavior. Drug therapy.

Highlighted excerpt: The incidence of anorectal sexually transmitted infections has increased over the last years, mainly due to the increase in the practice of unprotected receptive anal sexual intercourse.

\section{FOREWORD}

This article addresses sexually transmitted enteric infections, a topic that comprises the Clinical Protocol and Therapeutic Guidelines (PDCT) for Comprehensive Care for People with Sexually Transmitted Infections (STI), published by the Health Surveillance Department of the Brazilian Ministry of Health. For elaborating the PDCT, a selection and analysis of the evidence available in the literature were performed, and a panel of specialists discussed it. The document was approved by the National Committee for the Incorporation of Technologies in the Brazilian National Health System (Conitec) and updated by the panel of specialists in STI in $2020^{1}$.

\footnotetext{
Corresponding author: Thereza Cristina de Souza Mareco.

e-mail: thereza.mareco@aids.gov.br

(D) https://orcid.org/0000-0003-3402-2470

Received 01 February 2021

Accepted 10 March 2021
}

\section{EPIDEMIOLOGICAL ASPECTS}

Enteric pathogens and anorectal infections can be transmitted through different sexual practices without barrier protection in receptive anal or oroanal $\mathrm{sex}^{2}$. The transmission of diverse agents occurs naturally through the fecal-oral route, generally caused by consumption of contaminated food or water. Sexual transmission is well described, and it can happen through direct oroanal practice or indirectly through oral sex after anal penetration or through the use of fingers or fomites ${ }^{3}$.

Anorectal STI incidence has augmented over the last years, mainly due to the increased frequency of unprotected receptive anal sexual intercourse ${ }^{4}$. Anorectal intercourse is common, although its exact frequency stays unknown due to asymptomatic infections and the lack of accurate epidemiological data. People with symptoms or anorectal lesions are usually referred to coloproctologists for assessment and management ${ }^{5}$.

Risks to health arising from anal sex seem to be significantly underestimated by sexually active men and women in North America, Latin America, Asia, Africa, and other regions. Among heterosexual people, the reported prevalence of using condoms are almost universally lower in anal sex than in vaginal $\operatorname{sex}^{6}$. 
Outbreaks of sexually transmitted enteric infections in men with sex with men (MSM) show very similar characteristics. Generally, men report having multiple sexual partners ${ }^{7-10}$, attending places specifically for sexual encounters ${ }^{11-12}$ or particular sexual parties and using recreational drugs, including chemsex, or "chemical sex", sexual practice using crystal methamphetamine, gamma hydroxybutyrate, gamma-butyrolactone, or mephedrone immediately before or during $\operatorname{sex}^{8,10}$. Using the internet ${ }^{7}$ or geospatial network applications ${ }^{9-10}$ for finding casual partners that facilitate riskier behaviors is also commonly described ${ }^{13}$.

Among the $p$ enteric infections related to sexual transmission in MSM, hepatitis A, shigellosis, intestinal protozoan infections, such as amoebiasis and giardiasis, and bacterial gastroenteritis caused by Campylobacter spp. can be cited ${ }^{14}$. Herpes simplex virus, HSV, and Neisseria gonorrhea are also etiological agents of anorectal infections transmitted through anal sexual intercourse ${ }^{14}$.

Hepatitis A is a generally self-limited acute infectious disease caused by the hepatitis A virus, transmitted through the fecaloral route by ingesting contaminated food and water or intimate contact with an infected person ${ }^{15}$. Outbreaks associated with sexual transmission in MSM are described since 2016 by the European Centre for Disease Prevention and Control ${ }^{16,17}$. Symptoms after a four-week average incubation period are more common in adults and include fever, discomfort, nausea, anorexia, abdominal pain, and jaundice. Recurring hepatitis and acute hepatic insufficiency can also occur ${ }^{18}$. Shigellosis caused by the Gram-negative bacterium Shigella spp. is characterized by severe bacillary dysentery ${ }^{19,20}$. Regular sexual transmission outbreaks of Shigella sonnei and Shigella flexneri among MSM are reported since the $1970 \mathrm{~s}^{21,22}$. Sexually transmitted shigellosis is linked to different behaviors, including using douche, recreational drug use, and fisting, a practice consisting of forearm or hand introduction in the partner's vagina or anus ${ }^{8-10,11}$.

Proctocolitis is associated with food or water-transmitted diseases, including Shigella spp. ${ }^{23}$. It is characterized by watery or bleeding diarrhea, abdominal pain, tenesmus, and, sometimes, fever and discomfort from four to seven days ${ }^{24,25}$. Dissemination of multiresistant Shigella spp. infections through the sexual route have been reported ${ }^{26-28}$. Shigella spp. strains among MSM show increasing resistance to multiple drugs, mostly azithromycin and ciprofloxacin $^{29-33}$.

The foremost intestinal protozoan infections of interest within STI scope are giardiasis and amoebiasis. Annually millions of people develop these infections, but only $10 \%$ to $20 \%$ of the infected individuals become symptomatic. The risk of death is more remarkable for amoebiasis due to its invasive nature ${ }^{34}$. Such protozoan infections characteristically present higher prevalences in areas where sanitary conditions are inadequate, especially in Africa, in the Indian subcontinent, and parts of Central and South America. People who have traveled to developing countries are possible vectors ${ }^{35}$. Such infections are generally contracted through the fecaloral route by ingesting contaminated water or food ${ }^{36}$. The higher incidence of Entamoeba histolytica enteritis among homosexual men seems attributed to direct oral-anal sexual practice ${ }^{37,38}$ or through sex toys or fellatio. It can denote high-risk behavior and multiple exposures ${ }^{11}$. Giardiasis underdiagnosis in this context is frequent due to the low suspicion of such transmission routes ${ }^{39,40}$.

In giardiasis, the most common symptoms include diarrhea, oily stool, flatulence, and abdominal swelling ${ }^{41,42}$. There can be proctitis ${ }^{43}$. The average incubation period for giardiasis is one to two weeks, and the symptoms average three to ten weeks ${ }^{44}$. For amoebiasis, the wide specter of intestinal infection varies from asymptomatic to transitory intestinal inflammation up to fulminant colitis, including megacolon, peritonitis, and hepatic abscess ${ }^{35,45}$. The incubation period of intestinal amoebiasis is one to four weeks ${ }^{46}$.

Campylobacter spp. is one of the most worldwide common causes of bacterial gastroenteritis ${ }^{47,48}$. Many outbreaks have been reported, including resistance to antimicrobial drugs such as ciprofloxacin and macrolides ${ }^{49}$, Extra-intestinal infection is rare. Still, it can lead to complications, including bacteremia, lung infection, meningitis, or reactive arthritis, mainly in immunocompromised people ${ }^{47,48}$. Ingestion of contaminated food and water and contact with pets are among the principal forms of transmission. There are reports of fecal-oral sexual transmission in places of sexual encounters with recreational drug use $\mathrm{s}^{50,1}$.

HSV infections are characterized by chronicity and recurrence, with variable latency periods. There are two different strains: HSV2, responsible for genital lesions, and HSV-1, for extragenital ones, specially orolabial ${ }^{52}$. However, it is possible to find inversions in such order, without clinical specter differences. HSV-1 is commonly acquired in childhood and adolescence, while HSV-2 is linked to sexual activity. The infection risk increases with the number of sexual partners throughout life ${ }^{53}$.

Gonorrhea is a common bacterial infection, transmitted almost exclusively through sexual or perinatal contact, affecting mainly the urethral and cervical mucous membranes and, less frequently, those in the rectum, oropharynx, and conjunctive $\mathrm{e}^{54}$. Rectal $N$. gonorrhoeae infection is acquired through receptive anal intercourse and perineal contamination with cervicovaginal secretions. Around 35\% of women with gonococcal cervicitis will present a concurrent rectal infection through infection contiguous dissemination ${ }^{55}$.

\section{CLINICAL ASPECTS}

The presence of rectal bleeding and wounds or lesions in the anal and perianal area, possibly with pruritus and pain, producing secretions, indicate $\mathrm{STI}^{23}$.

Enteric pathogens cause gastroenteritis, which can have low (rectum) symptoms, such as pain, mucopurulent anal discharge, tenesmus and hematochezia, and high symptomatology (colon), such as diarrhea with a sudden start. When evolved with rectal distensibility loss, diarrhea becomes intense, and when the duodenum is compromised, vomits, and abdominal pains associated with colic occur ${ }^{56,57}$.

In severe cases, significant morbidity and mortality can be associated with diarrhea, dehydration, bacteremia, hemolytic uremia, and Guillain-Barré syndrome ${ }^{58-9}$. 
The most significant complications encompass inflammation of the rectal mucosa extending to the colon, with bleeding as a substantial sign, in addition to diarrhea, which leads to symptom intensification due to rectal distensibility loss. When the duodenum is compromised, vomits and abdominal pains associated with colic occur ${ }^{56}$.

\section{DIAGNOSIS}

Diagnosis based only on clinical aspects lacks specificity, requiring laboratory examination to identify the enteric infection etiological agent and define its sexual transmission.

Serological markers - IgM and anti-HAV IgG antibodies - are specific examinations for hepatitis A laboratory diagnosis. Leukopenia, aminotransferase, and high bilirubin findings are unspecific ${ }^{60}$.

For identifying Shigella spp., bacteria insulation is conducted in cultures, mainly in hemoculture and coproculture, in addition to sensitivity tests to antimicrobial drugs for following resistance and drug interaction possible cases.

Amoebiasis laboratory diagnosis is usually based on microscopic and serological methods, including enzyme-linked immunosorbent assay, ELISA, and indirect hemagglutination assay, latex agglutination, and tests based on nucleic acid amplification ${ }^{62}$. Intestinal amoebiasis diagnosis in many countries usually depends on fecal sampling microscopic examination regarding the presence or lack of E. histolytica and Giardia lamblia. The proportion of asymptomatic people infected with this protozoan is not clear ${ }^{62}$. The diagnosis must be confirmed by detecting $E$. histolytica-specific antigen in stool to distinguish it from other nonpathogenic amoebae. Serological tests can contribute to the diagnosis of invasive diseases, such as amoebiasis. However, their sensitivity can vary according to the disease's type and stage ${ }^{63}$. Eliminating cysts of $G$. lamblia can be intermittent and last for weeks. Therefore, many samples must be collected for diagnosis. Collecting three samples on different days ideally allows identifying cysts in more than $90 \%$ of the cases compared with $50 \%$ to $70 \%$ of those with a single sample. ELISA or antibody direct immunofluorescence can identify the parasite, with $88 \%-98 \%$ sensitivity and $87 \%-100 \%$ specificity ${ }^{64}$. Endoscopic methods with aspiration and duodenal biopsy may be needed in cases of diagnostic greater difficulty ${ }^{64,65}$.

Campylobacter spp. diagnosis is performed through isolation of the organism from stool samples or rectal swabs using selective media before starting antibiotic treatment. The culture identifies the subtype and susceptibility to antimicrobial drugs. Rapid tests for such pathogens, including antigen tests and nucleic acid-based tests, are available in Brazil ${ }^{65}$.

Diagnosis of herpes infection is based on the clinical aspect, especially if the condition is recurrent, and on laboratory examinations, such as viral culture, antigen detection, and polymerase chain reaction ${ }^{53}$. For diagnosis and laboratory investigation of gonorrhea in symptomatic cases, using a swab for anal culture, antibiogram, and molecular biology detection are recommended. On the other hand, for asymptomatic individuals with receptive anal practice without condom use, the recommendation is biannual follow-up through anal swab for detection through molecular biology, highlighting that culture is less sensitive than molecular biology techniques. Extragenital material samples, particularly anal and pharyngeal, and molecular biology tests must necessarily be validated for such collection sites ${ }^{14}$.

\section{TREATMENT}

Treatment of this infection group requires, at first, the identification or suspicion of the etiological agent, and it must start as soon as possible, not only aiming at relieving the symptoms but likewise other STI, also reducing transmission risk to other persons. Treatment includes antibiotics and parasiticide, in addition to hydroelectrolytic and symptomatic support medications.

Unspecific treatment for hepatitis A is conducted with hydration and symptomatic methods. The vaccine is the most efficient way for preventing transmission, which can also be applied after exposure together with immunoglobulin in people presenting high-risk ${ }^{66}$. For prevention in sexual contact, using an oral condom is the indication ${ }^{67}$.

The primary treatment for non-complicated Shigella spp. is conducted with ciprofloxacin, including azithromycin and ceftriaxone as alternative therapies. Prevention is accomplished through washing hands and food for consumption, in addition to sexual practices with protective barriers ${ }^{68-71}$, People living with human immunodeficiency virus, HIV, may have more severe and long-lasting shigellosis, mainly with T-CD4+ lymphocyte counting less than 200 cells $/ \mathrm{mm}^{3}$. Antimicrobial therapy may be extended for six weeks ${ }^{72}$. Meanwhile, changes in mucosae can be gateways for HIV ${ }^{25}$.

For amoebiasis and giardiasis treatment, using nitroimidazole compounds, such as metronidazole, tinidazole, and secnidazole, is the recommendation, with high cure proportions. Using such drugs is a contraindication for women in the first trimester of pregnancy, breastfeeding women, and people with neurological disorders ${ }^{35}$. Albendazole and nitazoxanide are antiparasitic medications with efficiency similar to metronidazole against giardiasis and can be used as an alternative, in daily doses, for five to three days, respectively ${ }^{73}$. For giardiasis, symptoms typically improve within five to seven days after starting treatment. In the case of chronic forms, improvement is slower. In case of diarrhea prolongation, it is possible to request a parasitological stool examination for excluding giardiasis persistence ${ }^{74,75}$. Complications include hypokalemia, undernutrition, growth delay, cognitive deficits, arthritis, myopathy, irritable bowel syndrome, and chronic fatigue $\mathrm{e}^{76,77}$.

Campylobacter spp. infection is self-limited and mild. Treatment is conducted with oral or parenteral hydration, depending on the disease severity and dehydration degree. Avoiding agents inducing intestinal mortality, as they can prevent infection resolution, is needed ${ }^{49}$. Antibiotics must also be considered for high-risk cases, such as immunocompromised and older people, and in case of more severe cases, with fever, hematochezia, or intense abdominal pain ${ }^{78}$. Antibiotic resistance, particularly resistance to fluoroquinolone, increased sharply since the 1990s. Different outbreaks were reported, including with resistance to antimicrobial drugs such as ciprofloxacin and macrolides ${ }^{48}$.

Treatment of HSV infection is based on using aciclovir and its derivatives valaciclovir and famciclovir, which present 
better absorption through oral route and bioavailability. Topical aciclovir or other antiviral is effective in reducing symptoms, and intravenous use of aciclovir is recommended for special situations, such as disseminated disease, meningoencephalitis pictures, and pneumonitis. In occurrence cases equal to or higher than six episodes per year, suppressive therapy is the recommendation. Suppressive treatment duration varies, but it is generally longer than six months ${ }^{50}$.

For confirming $N$. gonorrhoeae as the infectious agent, ceftriaxone associated with azithromycin is recommended ${ }^{14}$. Treatment can also be conducted with presumptive diagnosis based on anamnesis on the history of receptive anal sexual history without protection ${ }^{79}$.

\section{SURVEILLANCE, PREVENTION, AND CONTROL}

Through Consolidation Ordinance GM/MS no. 4, of September 28, 2017, all viral hepatitis became a compulsory notification matter ${ }^{80}$. However, hepatitis A has mandatory notification since $2003^{81}$. The required notification forms are available at the Ministry of Health's website ${ }^{82}$. Other STIs also have a compulsory report. Those that are not compulsory at the federal level can be included in the notification list of the Federal District, states, and municipalities, with free autonomy, surveillance, and control, as long as sanitary standards are observed.

The diseases addressed in this article are transmitted through unprotected sexual intercourse and contaminated water, and food ingestion. Therefore, in addition to condom regular use, the recommendation of not performing sexual actions that may facilitate direct contact with feces, basic prevention measures, and sanitation are crucial.

General basic preventive measures include frequently washing hands, especially when preparing food, before the meals and after going to the toilet; drinking filtrated and chlorinated water; washing fruit and vegetables, and not ingesting food suspected to be contaminated ${ }^{83,84}$.

Sanitation is comprehended as infrastructure and operational facilities for drinking water provision and sewage and urban cleaning with solid residue management and draining and urban rainwater management, generating better sanitary conditions for the population.

Vaccination against hepatitis A, which, according to the National Immunization Program, is recommended in a single dose for all children between 15 months and five years old, is also effective prevention. Coinfection with hepatitis A virus is frequent among HIV-infected MSM. Studies suggest that early vaccination against hepatitis A in people living with HIV may not provide reliable protection against infection development of such virus. Therefore, post-exposure prophylaxis, immunoglobulin application, and the monovalent vaccine may be considered in hepatitis A virus high-risk recent situations, regardless of prior vaccine situation ${ }^{66}$.

The cure control of sexually transmitted enteric infections occurs through clinical follow-up after specific treatment.

\section{ACKNOWLEDGMENTS}

The authors acknowledge this work's contribution by the members of the technical panel of specialists responsible for developing the 2020 PDCT for Comprehensive Care for People with STI.

\section{AUTHORS' CONTRIBUTIONS}

Nahn Jr EP, Oliveira EC, Barbosa MJ, Mareco TCS, and Brígido HA contributed with the concept, designing, drafting, and critical review of the manuscript. All the authors approved the final version of the work and are responsible for all its aspects, including the assurance of its accuracy and integrity.

\section{ORCID}

Edilbert Pelegrini Nahn Junior - 0000-0003-1656-3441

Eduardo Campos de Oliveira - 0000-0001-7066-9904

Marcelo Joaquim Barbosa - 0000-0002-0089-2366

Thereza Cristina de Souza Mareco - 0000-0003-3402-2470

Helena Andrade Brígido - 0000-0002-5065-4833

\section{REFERENCES}

1. Brasil. Ministério da Saúde. Portaria MS/SCTIE n ${ }^{\circ} 42$, de 5 de outubro de 2018. Torna pública a decisão de aprovar o Protocolo Clínico e Diretrizes Terapêuticas para Atenção Integral às Pessoas com Infecções Sexualmente Transmissíveis (IST), no âmbito do Sistema Único de Saúde - SUS [Internet]. Diário Oficial da União, Brasília (DF), 2018 Oct 8 [cited 2020 Sep 21];Seção I:88. Available from: http://bvsms.saude. gov.br/bvs/saudelegis/sctie/2018/prt0042 $08 \quad 10 \quad 2018 . h$ html

2. Jawale R, Lai KK, Lamps LW. Sexually transmitted infections of the lower gastrointestinal tract. Virchows Arch [Internet]. 2017 Jan [cited 2020 May 31];472(1):149-58. Available from: https://doi.org/10.1007/ $\underline{\mathrm{s} 00428-017-2261-5}$

3. Mitchell H, Hughes G. Recent epidemiology of sexually transmissible enteric infections in men who have sex with men. Curr Opin Infect Dis [Internet]. 2018 Feb [cited 2020 May 20];31(1):50-6. Available from: https://doi.org/10.1097/QCO.0000000000000423

4. Wexner SD. Sexually transmitted diseases of the colon, rectum, and anus. The challenge of the nineties. Dis Colon Rectum [Internet]. 1990 Dec [cited 2020 May 22];33(12):1048-62. Available from: https://doi. org/10.1007/BF02139224

5. Assi R, Hashim PW, Reddy VB, Einarsdottir H, Longo WE. Sexually transmitted infections of the anus and rectum. World J Gastroenterol [Internet]. 2014 Nov [cited 2020 Jun 12];20(41):15262-8. Available from: https://doi.org/10.3748/wjg.v20.i41.15262

6. Halperin DT. Heterosexual anal intercourse: prevalence, cultural factors, and HIV infection and other health risks, part I. AIDS Patient Care and STDS [Internet]. 1999 Dec [cited 2020 May 21];13(12):717-30. Available from: https://doi.org/10.1089/apc.1999.13.717

7. Marcus U, Zucs P, Bremer V, Hamouda O, Prager R, Tschaepe H, et al. shigellosis - a re-emerging sexually transmitted infection: outbreak in men having sex with men in Berlin. Int J STD AIDS [Internet]. 2004 Aug [cited 2020 May 22];15(8):533-7. Available from: https://doi. org/10.1258/0956462041558221

8. Mook P, McCormick J, Bains M, Cowley LA, Chattaway MA, Jenkins $\mathrm{C}$, et al. ESBL-Producing and macrolide-resistant Shigella sonnei 
infections among men who have sex with men, England. Emerg Infect Dis [Internet]. 2015 Nov [cited 2020 May 22];22(11):1948-52. Available from: https://doi.org/10.3201/eid2211.160653

9. Gilbart VL, Simms I, Jenkins C, Furegato M, Gobin M, Oliver I, et al. Sex, drugs, and smartphone applications: findings from semistructured interviews with men who have sex with men diagnosed with Shigella flexneri 3a in England and Wales. Sex Transm Infect [Internet]. 2015 Dec [cited 2020 May 22];91(8):598-602. Available from: https://doi. org/10.1136/sextrans-2015-052014

10. Simms I, Gilbart VL, Byrne L, Jenkins C, Adak GK, Hughes G, et al. Identification of verocytotoxin-producing Escherichia coli O117:H7 in men who have sex with men, England, November 2013 to August 2014. Euro Surveill [Internet]. 2014 Oct [cited 2020 May 21];19(43):20946. Available from: https://doi.org/10.2807/1560-7917.es2014.19.43.20946

11. O'Sullivan B, Delpech V, Pontivivo G, Karagiannis T, Marriott D, Harkness J, et al. Shigellosis linked to sex venues, Australia. Emerg Infect Dis [Internet]. 2002 Aug [cited 2020 Jun 10];8(8):862-4. Available from: https://doi.org/10.3201/eid0808.010534

12. Leentvaar-Kuijpers A, Kool JL, Veugelers PJ, Coutinho RA, van Griensven GJ. An outbreak of hepatitis a among homosexual men in Amsterdam, 1991-1993. Int J Epidemiol [Internet]. 1995 Feb [cited 2020 May 19];24(1):218-22. Available from: https://doi.org/10.1093/ije/24.1.218

13. McKenna KYA, Green AS, Smith PK. Demarginalizing the sexual self. J Sex Res [Internet]. 2001 Jan [cited 2020 May 19];38(4):302-11. Available from: https://doi.org/10.1080/00224490109552101

14. Ministério da Saúde (BR). Secretaria de Vigilância em Saúde. Departamento de Doenças de Condições Crônicas e Infecções Sexualmente Transmissíveis. Protocolo clínico e diretrizes terapêuticas para atenção integral às pessoas com infecções sexualmente transmissíveis (IST) [Internet]. Brasília: Ministério da Saúde; 2020 [cited 2020 Aug 28]. Available from: http://www.aids.gov.br/pt-br/ pub/2015/protocolo-clinico-e-diretrizes-terapeuticas-para-atencaointegral-pessoas-com-infeccoes

15. Ndumbi P, Freidl GS, Williams CJ, Mardh O, Varela C, Avellón A, et al. European Centre for Disease Prevention and Control. Hepatitis A outbreaks in the EU/EEA mostly affecting men who have sex with men: third update, June 28 2017. Stockholm, 2017. Euro Surveill [Internet]. 2018 Aug [cited 2020 Jun 13];23(33):1700641. Available from: https://doi.org/10.2807/1560-7917.ES.2018.23.33.1700641

16. Stene-Johansen K, Tjon G, Schreier E, Bremer V, Bruisten S, Ngui SL, et al. Molecular epidemiological studies show that hepatitis A virus is endemic among active homosexual men in Europe. J Med Virol [Internet]. 2007 Apr [cited 2020 Jun 20];79(4):356-65. Available from: https://doi.org/10.1002/jmv.20781.

17. São Paulo (Estado). Secretaria de Estado da Saúde. Coordenadoria de Controle de Doenças. Centro de Vigilância Epidemiológica "Prof. Alexandre Vranjac". Informe técnico: aumento de casos de hepatite A no Estado de São Paulo [Internet]. São Paulo: SES; 2017 [cited 2020 Aug 29]. Available from: http://nhe.fmrp.usp.br/wp-content/ uploads/2017/07/informe tecnico hepatite a.pdf

18. Koff RS. Clinical manifestations and diagnosis of hepatitis A virus infection. Vaccine [Internet]. 1992 [cited 2020 June 20];10(Suppl 1):S157. Available from: https://doi.org/10.1016/0264-410x(92)90533-p

19. Wilmer A, Romney MG, Gustafson R, Sandhu J, Chu T, Ng C, et al. Shigella flexneri serotype 1 infections in men who have sex with men in Vancouver, Canada. HIV Med. 2015 Feb [cited 2020 Jun 20];16(3):16875. Available from: https://doi.org/10.1111/hiv.12191

20. Cresswell FV, Ross S, Booth T, Nicolas OS, Eliza A, Jasmine B, et al. Shigella flexneri: a cause of significant morbidity and associated with sexually transmitted infections in men who have sex with men.
Sex Transm Dis [Internet]. 2015 Jun [cited 2020 June 22];42(6):344. Available from: https://doi.org/10.1097/OLQ.0000000000000295

21. Aragón TJ, Vugia DJ, Shallow S, Samuel MC, Reingold A, Ângulo FJ, et al. Case-control study of shigellosis in San Francisco: the role of sexual transmission and HIV infection. Clin Infect Dis [Internet]. 2007 Feb [cited 2020 Jun 22];44(3):327-34. Available from: https://doi. org/10.1086/510593

22. Wu HH, Shen YT, Chiou CS, Fang CT, Lo YC. Shigellosis outbreak among MSM living with HIV: a case-control study in Taiwan, 2015-2016. Sex Transm Infect [Internet]. 2019 Feb [cited 2020 Jun 24];95(1):67-70. Available from: https://doi.org/10.1136/sextrans-2017-053410

23. Felt-Bersma RJ, Bartelsman JF. Hemorrhoids, rectal prolapse, anal fissure, perianal fistulae, and sexually transmitted diseases. Best Pract Res Clin Gastroenterol [Internet]. 2009 Aug [cited 2020 Jun 22];23(4):57592. Available from: https://doi.org/10.1016/j.bpg.2009.04.010

24. Scallan E, Hoekstra RM, Angulo FJ, Tauxe RV, Widdowson MA, Roy SL, et al. Foodborne illness acquired in the United States--major pathogens. Emerg Infect Dis [Internet]. 2011 Jan [cited 2020 Jun 22];17(1):7-15. Available from: https://doi.org/10.3201/eid1701.p11101

25. Surawicz, CM. Shigella: a sexually transmitted infection in men who have sex with men. Gastroenterology [Internet]. 2007 Nov [cited 2020 Jun 22];133(5):1737-8. Available from: https://doi.org/10.1053/j. gastro.2007.09.044

26. Borg ML, Modi A, Tostmann A, Gobin M, Cartwright J, Quigley C, et al. Ongoing outbreak of Shigella flexneri serotype 3a in men who have sex with men in England and Wales, data from 2009-2011. Euro Surveill [Internet]. 2012 Mar [cited 2020 Jun 21];17(13):20137. Available from: https://pubmed.ncbi.nlm.nih.gov/22490381

27. Bowen A, Eikmeier D, Talley P, Siston A, Smith S, Hud J, et al. Notes from the field: outbreaks of Shigella sonnei infection with decreased susceptibility to azithromycin among men who have sex with Men Chicago and Metropolitan Minneapolis - St. Paul, 2014. MMWR Morb Mortal Wkly Rep [Internet[. 2015 Jun [cited 2020 June 21];64(21):597-8. Available from: https://www.ncbi.nlm.nih.gov/pmc/articles/PMC4584772

28. Hines JZ, Pinsent T, Rees K, Vines J, Bown A, Hurd J, et al. Notes from the field: shigellosis outbreak among men who have sex with men and homeless persons -Oregon, 2015-2016. MMWR Morb Mortal Wkly Rep [Internet]. 2016 Aug [cited 2020 Jun 21];65(31):812-3. Available from: https://www.cdc.gov/mmwr/volumes $/ 65 / \mathrm{wr} / \mathrm{mm} 6531 \mathrm{a} 5 . \mathrm{htm}$

29. Bernstein K, Bowen VB, Kim CR, Counotte MJ, Kirkcaldy RD, Kara $\mathrm{E}$, et al. Infecções sexualmente transmissíveis reemergentes e recentemente reconhecidas: as experiências anteriores podem esclarecer a identificação e o controle futuros? PLoS Med [Internet]. 2017 Dec [cited 2020 Jun 21];14(12):e1002474. Available from: https:// doi.org/10.1371/journal.pmed.1002474

30. Ingle DJ, Easton M, Valcanis M, Seemann T, Kwong JC, Stephens N, et al. Co-circulation of multidrug-resistant Shigella among men who have sex with men in Australia. Clin Infect Dis [Internet]. 2019 Nov [cited 2020 Jun 21];69(9):1535-44. Available from: https://doi.org/10.1093/cid/ciz005

31. Murray K, Reddy V, Kornblum JS, Waechter H, Chicaiz LF, Rubinstein I, et al. Increasing antibiotic resistance in Shigella spp. from Infected New York City residents, New York, USA. Emerg Infect Dis [Internet]. 2017 Feb [cited 2020 Jun 18];23(2):332-5. Available from: https://doi.org/10.3201/eid2302.161203

32. Chiou CS, Izumiya H, Kawamura M, Liao YS, Su YS, Wu HH, et al. The worldwide spread of ciprofloxacin-resistant Shigella sonnei among HIV-infected men who have sex with men, Taiwan. Clin Microbiol Infect [Internet]. 2016 Apr [cited 2020 Jun 18];22(4):383.e11-383.e16. Available from: https://doi.org/10.1016/j.cmi.2015.12.021 
33. Williamson D, Ingle D, Howden B. Extensively drug-resistant Shigellosis in Australia among men who have sex with men. N Engl J Med [Internet]. 2019 Dec [cited 2020 Jun 15];381(25):2477-9. Available from: https://doi.org/10.1056/NEJMc1910648

34. Van Hal SJ, Stark DJ, Fotedar R, Marriott D, Ellis JT, Harkness JL. Amoebiasis: current status in Australia. Med J Aust [Internet]. 2007 Apr [cited 2020 July 23];186(8):412-6. Available from: https://pubmed.ncbi. nlm.nih.gov/17437396

35. Haque R, Huston CD, Hughes M, Houpt E, Petri WA Jr. Amebiasis. N Engl J Med [Internet]. 2003 Apr [cited 2020 Jul 23];348(16):1565-73. Available from: https://doi.org/10.1056/NEJMra022710

36. Escolà-Vergé L, Arando M, Vall M, Rovira R, Espasa M, Sulleiro E, et al. Outbreak of intestinal amoebiasis among men who have sex with men, Barcelona (Spain). Euro Surveill [Internet]. 2017 Jul [cited 2020 July 23];22(30):30581. Available from: https://doi.org/10.2807/15607917.ES.2017.22.30.30581

37. Morán P, RamosF, Ramiro M, Curiel O, ConzálezE, ValadezA, etal. Infection by human immunodeficiency virus-1 is not a risk factor for amebiasis. Am J Trop Med Hyg [Internet]. 2005 Aug [cited 2020 Jul 23];73(2):296-300. Available from: https://pubmed.ncbi.nlm.nih.gov/16103593

38. Ortega HB, Borchardt KA, Hamilton R, Ortega P, Mahood J. Enteric pathogenic protozoa in homosexual men from San Francisco. Sex Transm Dis [Internet]. 1984 Apr [cited 2020 Jul 12];11(2):59-63. Available from: https://doi.org/10.1097/00007435-198404000-00001

39. Escobedo AA, Almirall P, Alfonso M, Cimerman S, Chacín-Bonilla L. Sexual transmission of giardiasis: a neglected route of spread? Acta Tropica [Internet]. 2014 Apr [cited 2020 Jul 13];132:106-11. Available from: https://doi.org/10.1016/j.actatropica.2013.12.025

40. Kean BH, William DC, Luminais SK. Epidemic of amoebiasis and giardiasis in a biased population. Br J Vener Dis [Internet]. 1979 Oct [cited 2020 July 13];55(5):375-8. Available from: https://www.ncbi.nlm. nih.gov/pmc/articles/PMC1045685/pdf/brjvendis00035-0063.pdf

41. Zylberberg HM, Green PH, Turner KO, Genta RM, Lebwohl B. Prevalence and predictors of Giardia in the United States. Dig Dis Sci [Internet]. 2017 Jan [cited 2020 July 10];62(2):432-40. Available from: https://doi.org/10.1007/s10620-016-4447-0

42. Feng Y, Xiao L. Zoonotic potential and molecular epidemiology of Giardia species and giardiasis. Clin Microbiol Rev [Internet]. 2011 Jan [cited 2020 Jul 15];24(1):110-40. Available from: https://doi.org/10.1128/CMR.00033-10

43. Kacker PP. A case of Giardia lamblia proctitis presenting in a V.D. clinic. Brit J Vener Dis [Internet]. 1973 [cited 2020 Jul 15];49(3):318-9. Available from: https://doi.org/10.1136/sti.49.3.318

44. Rosenthal PJ. Giardiasis. In: Papadakis MA, McPhee SJ, Rabow MW. Current medical diagnosis \& treatment [Internet]. 56th ed. [S.1.]:McGraw-Hill Education; 2017 [cited 2020 July 18]. Available from: http://accessmedicine.mhmedical.com/book.aspx?bookid=2683

45. Reed SL. Clinical manifestations and diagnosis. In: Ravdin JI, editor. Amebiasis [Internet]. London: Imperial College Press; 2000 [cited 2020 July 13]. p. 113-26. Available from: https://www.worldscientific.com/ doi/abs/10.1142/9781848160583 0005

46. Healy GR, Garcia LS. Intestinal and urogenital protozoa. In: Murray PR, Baron EJ, Pfaller MA, Tenover FC, Yolken RH, editors. Manual of clinical microbiology [Internet]. 6th ed. Washington, D.C.: ASM Press; 1995 [cited 2020 July 23]. p. 1204-28. Available from: https://www. asmscience.org/content/book/10.1128/9781555817381

47. Kaakoush NO, Castaño-Rodríguez N, Mitchell HM, Man SM. Global epidemiology of campylobacter infection. Clin Microbiol Rev [Internet]. 2015 Jun [cited 2020 Jul 20];28(3):687-720. Available from: https://doi. org/10.1128/CMR.00006-15
48. Man SM. The clinical importance of emerging Campylobacter species. Nat Ver Gastroenterol Hepatol [Internet]. 2011 Oct [cited 2020 Jun 23];8(12):669-85. Available from: https://doi.org/10.1038/ nrgastro.2011.191

49. Gaudreau C, Helferty M, Sylvestre JL, Allard R, Pilon PA, Poisson $\mathrm{M}$, et al. Campylobacter coli outbreak in men who have sex with men, Quebec, Canada, 2010-2011. Emerg Infect Dis [Internet]. 2013 May [cited 2020 July 14];19(5):764-7. Available from: https://doi.org/10.3201/ eid1905.121344

50. Centers for Disease Control and Prevention - CDC. Sexually transmitted diseases treatment guidelines, 2015. MMWR [Internet]. 2015 Jun [cited 2020 July 15];64(3). Available from: https://www.cdc.gov/std/tg2015/tg2015-print.pdf

51. Marchand-Senécal X, Bekal S, Pilon PA, Sylvestre JL, Gaudreau C. Campylobacter fetus cluster among men who have sex with men, Montreal, Quebec, Canada, 2014-2016. Clin Infect Dis [Internet]. 2017 Nov [cited 2020 Jul 14];65(10):1751-3. Available from: https://doi. org/10.1093/cid/cix610

52. Lupi O. Herpes simples, em rotinas de diagnóstico e tratamento das doenças infecciosas e parasitárias. In: Tavares W, Marinho LAC. Rotinas de diagnóstico e tratamento das doenças. São Paulo: Atheneu; 2005.

53. Jin SS. herpes simplex virus. In: Kuritzkes DR, Eron Jr J, editors. Practice hepatology and HIV. Physician continuing medical education (for Point of Care CME activities) [Internet]. [S.1.]: inPractice; 2016 [cited 2020 Aug 28]. Available from: https://www.inpractice.com/ textbooks/hiv/management of specific_disease_states/ch29_ptl_viral/ chapter-pages/page-2.aspx?origin $=2$.

54. Marrazzo JM, Apicella MA. Neisseria gonorrhoeae (Gonorrhea). In: Bennett JE, editors. Mandell, Douglas, and Bennett's principles and practice of infectious diseases. 9th ed. Philadelphia: Elsevier; 2020. p. 2608.

55. Beck D. Sexually transmitted diseases. In: Steele SR, Hull TL, Read TR, Saclarides TJ, Senagore AJ, Whitlow CB, editors. The ASCRS textbook of colon and rectal surgery. 2nd ed. New York: Springer; 2011. p. 295-307.

56. Quinn TC. Sexually transmitted enteric infections. In: Schlossberg D, editors. Clinical infectious disease [Internet]. Cambridge: Cambridge University Press; 2017 [cited 2020 July 14] p. 352-6. Available from: https://doi.org/10.1017/CBO9781139855952.060

57. Clutterbuck D, Asboe D, Barber T, Emerson C, Field N, Gibson S, et al. 2016 United Kingdom national guideline on the sexual health care of men who have sex with men. Int J STD AIDS [Internet]. 2018 Jan [cited 2020 August 10]. Available from: https://doi.org/10.1177/0956462417746897

58. Farthing M, Feldman R, Finch R, Fox R, Leen C, Mandal B, et al. The management of infective gastroenteritis in adults. A consensus statement by an expert panel convened by the British Society for the Study of Infection. J Infect [Internet]. 1996 Nov [cited 2020 Jul 14];33(3):143-52. Available from: https://doi.org/10.1016/s0163-4453(96)92057-5

59. DuPont HL. Acute infectious diarrhea in immunocompetent adults. $\mathrm{N}$ Engl J Med [Internet]. 2014 Apr [cited 2020 Jul 14];370(16):1532-40. Available from: https://doi.org/10.1056/NEJMra1301069

60. Bensabath G, Conde SRSS, Dias Junior LB, Demachki S. Hepatites virais. In: Leão RNQ, coordenador. Medicina tropical e infectologia da Amazônia. Belém: Samauma Editorial; 2013. p 675-739.

61. Clinical and Laboratory Standards Institute. M100-S26: Performance standards for antimicrobial susceptibility testing. 30th ed. [S.1]: CLSI; 2016 [cited $2020 \mathrm{Jul} 15$ ]. Available from: http://clsi.org/m100/

62. Krogstad DJ, Spencer HC Jr, Healy GR, Gleason NN, Sexton DJ, Herron CA. Amebiasis: epidemiologic studies in the United States, 1971-1974. Ann Intern Med [Internet]. 1978 Jan [cited 2020 Jun 27];88(1):89-97. Available from: https://doi.org/10.7326/0003-4819-88-1-89 
63. Abd-Alla MD, Jackson TG, Ravdin JI. Serum IgM antibody response to the galactose-inhibitable adherence lectin of Entamoeba histolytica. Am J Trop Med Hyg [Internet]. 1998 Sep [cited 2020 July 17];59(3):4314. Available from: https://doi.org/10.4269/ajtmh.1998.59.431

64. Nagaty IM, Hegazi MM. Dot-ELISA copro-antigen and direct stool examination in diagnosis of giardiasis patients. J Egypt Soc Parasitol [Internet]. 2007 Aug [cited 2020 July 13];37(2):641-8. Available from: https://emedicine.medscape.com/article/176718-workup

65. Centers for Disease Control and Prevention - CDC. Yellow book 2020: health information for international travel. Washington, D.C.: CDC; 2020 [cited 2020 Jun 29]. Available from: https://wwwnc.cdc.gov/travel/ yellowbook/2020/travel-related-infectious-diseases/campylobacteriosis

66. Brennan J, Moore K, Sizemore L, Mathieson AS, Wester C, Dunn JR, et al. Notes from the field: acute hepatitis A virus infection among previously vaccinated persons with HIV infection - Tennessee, 2018. MMWR Morb Mortal Wkly Rep [Internet]. 2019 Apr [cited 2020 Jun 20];68(14):328-9. Available from: https://doi.org/10.15585/mmwr. mm6814a3

67. Ruscher C, Werber D, Thoulass J, Zimmermann R, Eckardt M, Winter $\mathrm{C}$, et al. Dating apps and websites as tools to reach anonymous sexual contacts during an outbreak of hepatitis A among men who have sex with men, Berlin, 2017. Euro Surveill [Internet]. 2019 May [cited 2020 Jun 21];24(21):1800460. Available from: https://doi.org/10.2807/15607917.ES.2019.24.21.1800460

68. World Health Organization - WHO. Guidelines for the control of shigellosis, including epidemics due to Shigella dysenteriae type 1 [Internet]. Geneva: World Health Organization; 2005 [cited 2020 Sep 22]. Available from: https://www.who.int/cholera/publications/ shigellosis/en/

69. Bowen A, Grass J, Bicknese A, Campbell D, Hurd J, Kirkcaldy RD. Elevated risk for antimicrobial drug-resistant Shigella infection among men who have sex with men, United States, 2011-2015. Emerg Infect Dis [Internet]. 2016 Sep [cited 2020 Jun 21];22(9):1613-6. Available from: https://doi.org/10.3201/eid2209.160624

70. Baker KS, Dallman TJ, Ashton PM, Day M, Hughes G, Crok PD, et al. Intercontinental dissemination of azithromycin-resistant shigellosis through sexual transmission: a cross-sectional study. Lancet Infect Dis [Internet]. 2015 Apr [cited 2020 July 13];15(8):913-21. Available from: https://doi.org/10.1016/S1473-3099(15)00002-X

71. Wong MR, Reddy V, Hanson H, Johnson KM, Tsoi B, Cokes C, et al. Antimicrobial resistance trends of Shigella serotypes in New York City, 2006-2009. Microb Drug Resist [Internet]. 2010 [cited 2020 Jun 29];16(2):155-16. Available from: https://doi.org/10.1089/mdr.2009.0130

72. Centers for Disease Control and Prevention - CDC. National Institutes of Health. HIV Medicine Association of the Infectious Diseases Society of America. US Department of Health and Human Services. Panel on opportunistic infections in HIV-infected adults and adolescents. Guidelines for the prevention and treatment of opportunistic infections in HIV-infected adults and adolescents [Internet]. Washington, D.C.: CDC; 2020 [cited 2020 Jul 10]. Available from: https://aidsinfo.nih.gov/ contentfiles/lvguidelines/adult_oi.pdf
73. Cimerman S, Cimerman B. Parasitoses intestinais: protozooses intestinais. In: Cimerman S, Cimerman B. Conduta em infectologia [Internet]. São Paulo: Atheneu; 2004 [cited 2020 Jun 29]. p. 329-342. Available from: https://pesquisa.bvsalud.org/portal/resource/pt/lil-407428

74. Hooshyar H, Rostamkhani P, Arbabi M, Delavari M. Giardia lamblia infection: review of current diagnostic strategies. Gastroenterol Hepatol Bed Bench [Internet]. 2019 Winter [cited 2020 Sep 22];12(1):3-12. Available from: https://pubmed.ncbi.nlm.nih.gov/30949313/

75. Busatti HG, Santos JF, Gomes MA. The old and new therapeutic approaches to the treatment of giardiasis: where are we? Biologics [Internet]. 2009 [cited 2020 Jun 30];3:273-287. Available from: https:// pubmed.ncbi.nlm.nih.gov/19707415

76. Halliez MC, Buret AG. Extra-intestinal and long-term consequences of Giardia duodenalis infections. World J Gastroenterol [Internet]. 2013 Dec [cited 2020 Jun 29];19(47):8974-85. Available from: https://doi. org/10.3748/wjg.v19.i47.8974

77. Munoz FM. Treatment and prevention of giardiasis. Waltham (MA): UpToDate; 2015 [cited 2020 Jun 29]. Available from: http://www. uptodate.com/contents/treatment-and-prevention-of-giardiasis

78. Ruiz-Palacios GM. The health burden of Campylobacter infection and the impact of antimicrobial resistance: playing chicken. Clin Infec Dis [Internet]. 2007 Mar [cited 2020 Jun 22];44(5):701-3. Available from: https://doi.org/10.1086/509936

79. Shover CL, Beymer MR, Unger EM, Javanbakht M, Bolan RK. Accuracy of presumptive gonorrhea treatment for gay, bisexual, and other men who have sex with men: results from a large sexual health clinic in Los Angeles, California. LGBT Health. 2018 Mar [cited 2020 Jun 22];5(2):139-44. Available from: https://doi.org/10.1089/lgbt.2017.0115

80. Ministério da Saúde (BR). Nota Informativa no 55/2019-CGAE/. DIAHV/ SVS/MS. Orientações acerca dos critérios de definição de casos para notificação de hepatites virais [Internet]. Brasília: Ministério da Saúde; 2019 [cited 2020 Jun 20]. Available from: http://portalsinan.saude.gov. br/images/documentos/Agravos/Hepatites Virais/Nota_Informativa Hepatites Virais.pdf

81. Brasil. Ministério da Saúde. Gabinete do Ministro. Portaria MS/GM n 2.325 , de 8 de dezembro de 2003. Define a relação de doenças de notificação compulsória para todo território nacional [Internet]. Diário Oficial da União, Brasília (DF), 2003 Dec 10 [cited 2020 Jul 20];Seção I:81. Available from: http://bvsms.saude. gov.br/bvs/saudelegis/gm/2003/prt2325 08 12_2003.html

82. Ministério da Saúde (BR). Sistema de Informação de Agravos de Notificação. Sinan-Net [Internet]. Brasília: Ministério da Saúde; 2020 [cited $2020 \mathrm{Jul}$ 31]. Available from: http://portalsinan.saude.gov.br

83. Erickson MC, Ortega YR. Inactivation of protozoan parasites in food, water, and environmental systems. J Food Prot [Internet]. 2006 Nov [cited 2020 Jun 29];69(11):2786-808. Available from: https://doi. org/10.4315/0362-028x-69.11.2786

84. Shirley DAT, Farr L, Watanabe K, Moonah S. A Review of the global burden, new diagnostics, and current therapeutics for amebiasis. Open Forum Infec Dis [Internet]. 2018 Jul [cited 2020 June 29];5(7):ofy161. Available from: https://doi.org/10.1093/ofid/ofy161 